\title{
NAUCZANIE ANGIELSKIEJ FRAZEOLOGII LOTNICZEJ
}

\begin{abstract}
Słowa kluczowe: komunikacja lotnicza, angielski język lotniczy, frazeologia lotnicza, instruktor frazeologii lotniczej, nauczanie frazeologii lotniczej

Streszczenie. Komunikacja w lotniczym języku angielskim ma bardzo duże znaczenie dla bezpieczeństwa lotniczego, dlatego użytkowanie przestrzeni powietrznej, a także stosowanie w niej angielskiego języka lotniczego zostało uregulowane międzynarodowymi przepisami. Angielski język lotniczy składa się z dwóch komponentów: frazeologii lotniczej oraz uproszczonego języka angielskiego stosowanego w komunikacji specjalistycznej. Artykuł przybliża zagadnienie frazeologii lotniczej, podając nie tylko zakres jej stosowania, lecz także zwracając uwagę na specyfikę jej nazwy w języku polskim. Druga część artykułu poświęcona jest nauczaniu angielskiej frazeologii lotniczej w ściśle hermetycznych polskich realiach. Autorka wskazuje także różnice pomiędzy instruktorem frazeologii lotniczej a nauczycielem języka angielskiego.
\end{abstract}

\section{WPROWADZENIE}

Przestrzeń powietrzna jest postrzegana jako bogactwo naturalne państwa, posiadające $\mathrm{z}$ jednej strony walory ekonomiczne, a $\mathrm{z}$ drugiej - będące częścią środowiska naturalnego ludzi. Dlatego powinna być w odpowiedzialny sposób zagospodarowywana, użytkowana i chroniona. Służy temu jej klasyfikowanie z jednoczesnym wprowadzaniem przepisów i procedur regulujących działania użytkowników. Dla uporządkowania ruchu statków powietrznych w przestrzeni wyznacza się drogi lotnicze, strefy i granice, wewnątrz których obowiązują zakazy i nakazy opracowywane w celu zabezpieczenia potrzeb wzrastającej liczby użytkowników i zapewnienia im maksymalnego, możliwego do osiągnięcia poziomu bezpieczeństwa, bez nadmiernego ograniczania swobody poruszania się w tym środowisku (Glen, Marud 2005, s. 97). Lotnictwo jest szczególnym

*a.borowska@uw.edu.pl; Aviation Communication Research Centre, Instytut Komunikacji Specjalistycznej i Interkulturowej, Wydział Lingwistyki Stosowanej, Uniwersytet Warszawski, ul. Szturmowa 4, 02-678 Warszawa. 
rodzajem działalności ludzkiej podatnej na zagrożenia. Jedyna możliwość ich uniknięcia to minimalizacja prawdopodobieństwa ich wystąpienia i ograniczenia ewentualnych tego skutków.

Ruch lotniczy jest regulowany przepisami organizacji międzynarodowych. Występuje w wydzielonych obszarach przestrzeni powietrznej-drogach lotniczych i korytarzach - o zdefiniowanych granicach bocznych, wysokości dolnej i górnej, łączących poszczególne punkty kontrolne. W międzynarodowej komunikacji lotniczej w celu zwiększenia skuteczności, podniesienia efektywności i zapewnienia bezpieczeństwa działań wszystkim użytkownikom przestrzeni powietrznej stosuje się specjalistyczny angielski język lotniczy (ang. Aviation English, zwany także Aeronautical English). W jego ramach wyodrębniono dwa podzbiory służące celom ściśle określonej komunikacji lotniczej: 1) angielską frazeologię lotniczą (ang. aviation standard phraseology) stosowaną podczas sytuacji rutynowych, czyli przewidywalnych, we wszystkich fazach lotu oraz 2) uproszczony język angielski (ang. plain English) wykorzystywany podczas sytuacji nagłych lub naglących.

Wymianę informacji z użytkownikami umożliwia system łączności. Środki łączności stosowane w systemie to środki służb kontroli ruchu lotniczego. W przestrzeni powietrznej zasadniczą formą komunikacji pomiędzy służbami kontroli powietrznej a jej użytkownikami jest łączność foniczna, realizowana za pomocą radiostacji zakresów VHF, UHF, HF. Do wymiany informacji cyfrowej (zarówno tekstowej jak i fonicznej) wykorzystuje się kilka standardów, znanych powszechnie jako link. Przestrzeń powietrzna służb kontroli ruchu lotniczego obejmuje segmenty przestrzeni o zdefiniowanych granicach, w których służby ruchu lotniczego są zapewniane dla lotów wykonywanych z widzialnością (Visual Flight Rules w celu zwiększenia skuteczności, podniesienia efektywności i zapewnienia bezpieczeństwa działań wszystkim użytkownikom przestrzeni powietrznej - VFR) i według przyrządów (Instrumental Flight Rules - IFR). Zgodnie z przepisami Organizacji Międzynarodowego Lotnictwa Cywilnego - ICAO ${ }^{1}$, państwa organizujące swą przestrzeń powietrzną jako rejon informacji powietrznej (Flight Information Region - FIR) i górny rejon informacji powietrznej (Upper Flight Information Region - UIR) są zobowiązane do zapewnienia jako minimum służby informacji powietrznej i alarmowej. Istnieją następujące rodzaje służb ruchu lotniczego, zwane Air Traffic Services - ATS:

1. Służba kontroli ruchu lotniczego (Air Traffic Control - ATC), która ma na celu zapobieganie wzajemnym kolizjom statków powietrznych w locie i na polu manewrowym lotniska oraz usprawnienie i uporządkowanie przepływu ruchu lotniczego. Na służby ATC składają się:

- $\quad$ służba kontroli obszaru (Area Control Service), zapewniająca kontrolę ruchu lotniczego w odniesieniu do lotów kontrolowanych w celu zapobiegania wzajemnym

${ }^{1}$ ICAO - ang. International Civil Aviation Organization - Organizacja Międzynarodowego Lotnictwa Cywilnego. 
kolizjom statków powietrznych w locie oraz porządkowania przepływu ruchu lotniczego;

- $\quad$ służba kontroli zbliżania (Approach Control Service), zapewniająca kontrolę ruchu lotniczego w odniesieniu do części lotów kontrolowanych związanych z przylotem i odlotem od lotniska w celu zapobiegania wzajemnym kolizjom statków powietrznych w locie oraz porządkowania przepływu ruchu lotniczego;

- $\quad$ służba kontroli lotniska (Aerodrome Control Service), zapewniająca kontrolę ruchu lotniczego w odniesieniu do ruchu lotniskowego w celu zapobiegania wzajemnym zderzeniom statków powietrznych lub ich zderzeniom z przeszkodami na polu manewrowym lotniska;

2. Służba informacji powietrznej (Flight Information Service - FIS), której zadaniem jest udzielanie wskazówek i informacji użytecznych dla bezpiecznego i sprawnego wykonywania lotów;

3. Służba alarmowa (Alerting Service - ALRS), której zadaniem jest zawiadamianie organu odpowiedzialnego za uruchomienie systemu ratownictwa lotniczego o statkach powietrznych potrzebujących pomocy i współdziałanie z tym organem w razie potrzeby ${ }^{2}$.

\section{STAN PRAWNY}

Wszystkie wymienione służby oraz załogi statków powietrznych, zarówno cywilne, jak i wojskowe, są obecnie zobowiązane przepisami międzynarodowymi do biegłego posługiwania się angielskim językiem lotniczym. Potencjalne problemy w posługiwaniu się wspólnym językiem wpływają na szybkość i sprawność wymiany informacji. Słaba znajomość języka angielskiego powoduje nie tylko ograniczenia w zakresie przekazywanych danych, ale może stać się źródłem nieporozumień. Mając powyższe na uwadze, we wrześniu 2003 r. ICAO wprowadziła zmiany w przepisach dotyczących podniesienia ogólnych wymagań językowych. Pierwsza informacja o konieczności poddania się testom potwierdzającym poziom znajomości lotniczego języka angielskiego wśród pilotów i kontrolerów ruchu lotniczego została opublikowana przez ICAO 27 listopada 2003 r. w postaci 164 zmiany do Aneksu I do Konwencji Chicagowskiej. Modyfikacje te miały obowiązywać od marca 2008 r., jednak na 36. Zgromadzeniu ICAO, w październiku 2007 r. przesunięto tę datę na 5 marca 2011 r. Od tego czasu wszyscy czynni piloci obsługujący trasy międzynarodowe i wszyscy kontrolerzy, którzy komunikują się z takimi pilotami muszą poddawać się ocenie poziomu znajomości lotniczego języka angielskiego i wykazać się umiejętnością mówienia i rozumienia ze słuchu na co najmniej 4. poziomie operacyjnym (z 6 możliwych) oraz uzyskanie potwierdzającego ten fakt wpisu do licencji ${ }^{3}$.

${ }^{2}$ Zob. ATS Planning Manual, ICAO Doc 9426 i Rozporządzenie Ministra Infrastruktury z dnia 11 marca 2004 r. w sprawie zasad działania stużb ruchu lotniczego.

${ }^{3}$ Zob. Rozporzadzenie Ministra Infrastruktury z dnia 3 września w sprawie licencjonowania personelu lotniczego (Dz.U. Nr 165, poz. 1603, z późn. zm.) 
„Przesunięcie” polegało na tym, że państwa członkowskie ICAO dostały zgodę na to, aby po 5 marca 2008 r., według własnego uznania, wpuszczać lub nie, pilotów z państw obcych do swojej przestrzeni powietrznej bez wymaganego wpisu do licencji, potwierdzającego znajomość języka angielskiego na wymaganym poziomie. Po 5 marca 2011 r. piloci bez wymaganego wpisu nie mogą już uzyskać zgody na przebywanie w przestrzeni innego państwa, a po wykryciu braku wpisu English Proficiency (EP) w licencji, np. w ramach inspekcji SAFA (Safety Assessment of Foreign Aircraft - EC SAFA Programme) na obcym lotnisku, samolot jest uziemiany, a pilot wraca do kraju jako pasażer (Krasnodębska 2010).

Rozporządzenia ICAO nakazują pilotom i kontrolerom biegle komunikować się, stosując standardową frazeologię $\mathrm{ICAO}^{4} \mathrm{w}$ sytuacjach rutynowych i uproszczony lotniczy język angielski ${ }^{5} \mathrm{w}$ sytuacjach awaryjnych lub niestandardowych. W dokumencie ICAO nr 9835 wymieniono 6 poziomów biegłości językowej i ściśle scharakteryzowano każdy z nich, przy czym, jak wspomniano, za minimalny wymagany poziom uznano 4 . Powyższe regulacje prawne zostały przyjęte także przez Federalną Administrację Lotnictwa w USA (ang. FAA - Federal Aviation Administration):

The U.S. has notified ICAO that it file a difference that will extend the U.S. compliance date until March 5, 2009 in order to provide sufficient time for all affected U.S. airman certificate holder to comply with the ICAO Language Proficiency airman certificate endorsement requirements ${ }^{6}$.

Jednak w przypadku rodzimych użytkowników języka angielskiego nie praktykuje się kursów czy egzaminów z frazeologii lotniczej. Wychodzi się z założenia, że tego rodzaju użytkownikom nie jest to potrzebne:

Their [native speakers' of English] effective use of English in aviation contexts is usually taken for granted, as in Aeronautical Aviation Publication (Borowska 2016: s. 62): "...the U.S. does not require air traffic controllers or aeronautical station operators to demonstrate the ability to speak and understand the language" (FAA 2009: section GEN 1.7).

Obowiązkiem państwa członkowskiego ICAO jest przeprowadzenie weryfikacji poziomu znajomości języka angielskiego oraz dokonanie wymaganego przepisami wpisu do licencji wraz z określeniem poziomu językowego. Do polskiego systemu prawnego obowiązek wykazania się przez kandydata umiejętnością mówienia i rozumienia ze słuchu na poziomie 4. operacyjnym, wymaganym przez Aneks 1, wprowadził Minister Infrastruktury ${ }^{7}$.

${ }^{4}$ ICAO Doc. 9432.

${ }^{5}$ ICAO Doc. 9835.

${ }^{6}$ FAA Flight Standards Service: Washington, DC 2/28/08.

${ }^{7}$ Zmiana rozporządzenia Ministra Infrastruktury z dnia 3 września w sprawie licencjonowania personelu lotniczego (Dz.U. Nr 165, poz. 1603, z późn. zm.) obowiązującego od 1 sierpnia 2009 r. 
Głównym celem egzaminów językowych, zgodnie z zaleceniami ICAO, nie jest wyłącznie sprawdzenie znajomości angielskiej frazeologii lotniczej, ale przede wszystkim umiejętności płynnego posługiwania się lotniczym językiem angielskim w sytuacjach awaryjnych. Nie da się jednak uniknąć standardowych formuł komunikacyjnych stosowanych pomiędzy załogą statku powietrznego a kontrolerem podczas samego egzaminu. Frazeologia lotnicza w języku angielskim zazwyczaj jest bardzo dobrze znana zdającym. Z obserwacji Urzędu Lotnictwa Cywilnego wynika, że nie stanowi ona problemu, a nawet przeciwnie, dla czynnych pilotów i kontrolerów lotu jest najłatwiejszą częścią testu. Może jednak być przeszkodą nie do pokonania dla tzw. ,amatorów”, tj. osób, które nie miały nigdy z nią do czynienia (Krasnodębska 2010) ${ }^{8}$.

W części zasadniczej egzaminu z języka angielskiego w Krajowym Systemie Egzaminów Językowych, sprawdzającej umiejętność wysławiania się i komunikowania (tzw. Speaking), zadanie nr 1 (z 3) polega na ,sprawdzeniu komunikacji w relacji pilot-kontroler, kontroler-kontroler, pilot-informator FIS itp. w sytuacjach standardowych z użyciem frazeologii lotniczej w tematyce właściwej dla pracy pilotów i kontrolerów ruchu lotniczego"9. W obowiązującym dotychczas w Polsce, ale wygaszanym obecnie przez Urząd Lotnictwa Cywilnego ${ }^{10}$, egzaminie z języka angielskiego w oparciu o system ELPAC (English Language Proficiency for Aeronautical Communication) część ustna polega m.in. na sprawdzeniu odpowiedniego stosowania frazeologii ICAO, w tym także w połączeniu $\mathrm{z}$ uproszczonym lotniczym językiem angielskim ${ }^{11}$.

\section{FRAZEOLOGIA LOTNICZA}

$\mathrm{Na}$ uwage zasługuje sama nazwa frazeologia lotnicza stosowana w języku polskim jako kalka z języka angielskiego (ang. aviation standard phraseology). Termin ten może być błędnie rozumiany i mylący dla szerszego grona odbiorców ze względu na znaczenie słowa frazeologia funkcjonującego na gruncie polskim zgodnie ze Stownikiem języka polskiego pod red. W. Doroszewskiego jako:

frazeologia [gr. phrásis 'wyrażanie się', lógos 'słowo', 'nauka']:

1) «zasób związków frazeologicznych właściwych danemu językowi»

2) «dział językoznawstwa badający związki frazeologiczne danego języka»

3) lekcew. «o ozdobnych wyrażeniach i zwrotach pozbawionych głębszej treści»;

\footnotetext{
${ }^{8} \mathrm{http} / /$ dlapilota.pl/wiadomosci/dlapilota/icao-level-4-prawdy-i-mity-o-egzaminach-z-jezykaangielskiego-w-ulc [12.07.2015].

${ }^{9}$ www.ulc.gov.pl

${ }^{10}$ Dane z 4.05.2016 r.: www.ulc.gov.pl

${ }^{11}$ Zob. Eurocontrol, ELPAC: Test Taker Preparation, v3.0.
} 
lub na podstawie Praktycznego stownika terminów literackich pod red. H. Sułka:

\section{frazeologia}

- jeden z podsystemów systemu językowego, obejmujący związki frazeologiczne, tzn. połączenia wyrazowe o charakterze stałym (leksykalne związki frazeologiczne, często idiomatyczne) lub przygodnym;

- nauka badająca związki frazeologiczne.

Żadna z powyższych definicji nie jest prawdziwa dla omawianej frazeologii lotniczej. Nie jest to ani dyscyplina naukowa, ani nawet zbiór związków frazeologicznych występujących w języku awiacji ${ }^{12}$. Można jednak powiedzieć, że frazeologia lotnicza zawiera swoiste formalne związki frazeologiczne, będące wielowyrazowymi wypowiedzeniami, mającymi tylko jedno znaczenie i tylko jedną, stałą postać ze względu na szczególną funkcję (Müldner-Nieckowski 2007), np. instrukcje kontrolera: cleared to take off lub komunikaty pilota: runway vacated. Jednak frazeologia lotnicza nie ogranicza się tylko do takich związków, ale przede wszystkim obejmuje sposób formułowania wypowiedzi charakterystyczny dla omawianej grupy zawodowej bez konieczności szczegółowego opisywania podejmowanej czynności, a z wykorzystaniem znanego zbioru terminów i wyrażeń, tak jak określają to definicje w języku źródłowym:

phraseology

1) a manner of organizing words and phrases into longer elements;

2) choice of words. (http://www.merriam-webster.com/dictionary);

oraz

1) the way in which words and phrases are used in speech or writing style;

2) a set of expressions used by a particular person or group, e.g. nautical phraseology; manner or style of verbal expression; characteristic language: legal phraseology. (www.thefreedictionary.com).

Frazeologia lotnicza składa się zatem ze ściśle ustalonych sformalizowanych zwrotów, stosowanych dla procedur operacyjnych, a także określa sposób nadawania liczb i liter wraz ze zmienioną w celu uniknięcia dwuznaczności wymową niektórych cyfr, a także niektórych wyrazów, tj. affirm. ICAO określa cel standardowej frazeologii lotniczej, zaznaczając wyraźnie, że stanowi ona tylko element lotniczego języka angielskiego i nie wystarczy do komunikacji lotniczej we wszystkich jej aspektach:

Frazeologia ICAO ma na celu stworzenie jasnej, zwięzłej i jednoznacznej formy komunikacji w łączności pomiędzy pilotami i personelem służb ruchu lotniczego. Z założenia nie obejmuje ona wszystkich przypadków mogących mieć miejsce w ruchu lotniczym, a jedynie określa sposób komunikowania się w sytuacjach standardowych. Wszędzie

${ }^{12}$ Ponadto stosowanie wyrażeń idiomatycznych jest zabronione. 
tam, gdzie jest to możliwe, należy używać obowiązujących zwrotów i wyrażeń frazeologicznych, w pozostałych zaś przypadkach można posłużyć się tzw. tekstem otwartym. W takich sytuacjach trzeba przede wszystkim pamiętać o tym, aby wypowiedzi były jasne, zwięzłe i jednoznaczne.

Oznacza to, że poza znajomością frazeologii lotniczej personel ATS oraz piloci powinni osiągnąć odpowiedni poziom znajomości języka angielskiego ${ }^{13}$.

Dzięki takiej praktyce porozumiewanie się użytkowników przestrzeni powietrznej z personelem naziemnym staje się zwięzłe i precyzyjne.

Choć sama frazeologia niewątpliwie jest narzędziem pracy zawodowej, jest monosemiczna, bez konotacji ekspresywnych, jest także utworzona na podstawie języka naturalnego (co pozwala nazwać ją językiem aposteriorycznym), to jednak wyróżnia się pewnymi cechami, które wyraźnie dyskwalifikują ją jako (sub)język. Frazeologia lotnicza nie służy poznawaniu i nazywaniu nowych zjawisk, nie naśladuje składni języka naturalnego, nie umożliwia tworzenia nieskończonej liczby wyrażeń syntaktycznych w swoim obrębie, ale wyróżnia się w warstwie fonetycznej, tworzy system zamknięty, hermetyczny, w którym wprowadzenie nowych jednostek leksykalnych wymaga testowania i uzasadnienia. Poprzez wprowadzenie ścisłych procedur oddalono się od języka ogólnego tak skutecznie, że jedną z głównych cech tejże frazeologii stał się wyraźnie zaznaczony charakter kodowy. Ma ona na celu komunikację ściśle zawodową, więc skoro nie może być nazwana (sub) językiem, może być traktowana jako swoista odmiana języka specjalistycznego.

Ponadto w angielskiej frazeologii lotniczej można wyodrębnić zbiór jednostek leksykalnych właściwy dla komunikacji zawodowej, spójny konceptualnie i unikatowy semantycznie. Za jednostkę leksykalną uznaje się tu wyraz lub leksem. Prymarną funkcją frazeologii jest oczywiście funkcja komunikacyjna. Samo porozumiewanie się personelu lotniczego powinno przebiegać poprawnie i sprawnie, bo nie ma tu miejsca na naukową interpretację jakiegoś wycinka rzeczywistości.

Nie służy ona też poznaniu. Stosowane zwroty i terminy ułatwiają zrozumienie, redukując możliwości błędnego zrozumienia przekazu wykonywanych ogólnych procedur operacyjnych, podczas których frazeologia służy m.in. do:

- nadawania liter, liczb i czasu;

- wywoływania stacji kontroli lub statku powietrznego;

- nawiązywania łączności;

- przekazywania łączności;

- udzielania zezwoleń i żądania powtórzeń;

- przeprowadzania procedur sprawdzania (Fellner \& Zając 2008, s. 43).

Uczestnicy dialogu lotniczego muszą wykazać się wiedzą dotyczącą treści oraz procedur, za pomocą których te treści będą wykonane. To reguły normatywne języka lotniczego pomagają im w wyborze reakcji właściwej w danej sytuacji komunikacyjnej. Interpretacja tego, co znaczą określone wypowiedzi, wpływa na

13 ICAO Doc 9432 AN/9, Podręcznik radiotelefonicznej frazeologii lotniczej, 2007, s. iii. 
rodzaj reakcji werbalnej, do której piloci i kontrolerzy są zobowiązani, a która może być dozwolona lub zakazana, np. prośba o powtórzenie komunikatu: zalecane wyrażenie SAY AGAIN, niedozwolone: *repeat (Borowska 2012, s. 25).

Jednak frazeologia ta nie jest stosowana poprawnie w każdym regionie świata, a często personel operacyjny zamiast niej używa ogólnego języka angielskiego. Potwierdzają to przeprowadzane badania. Dwuznaczna lub niestandardowa frazeologia często przyczynia się do wypadków i incydentów lotniczych, a odchodzenie od jej stosowania pozostawia komunikaty wolnej interpretacji (IATA 2011). Na jedno z pytań zadanych w swoim badaniu przez IATA (2011): 'In what region do you most often experience an event where ICAO standard phraseology is NOT used? ${ }^{14}$, odpowiedzi wskazały region Ameryki Północnej jako 27\%, a zaraz po nim region Europy jako 22\% (IATA 2011, s. 14), jak przedstawiono w poniższej tabeli:

Tabela 1. Regiony, w których najczęściej występuje brak stosowania frazeologii lotniczej podczas komunikacji pilot-kontroler

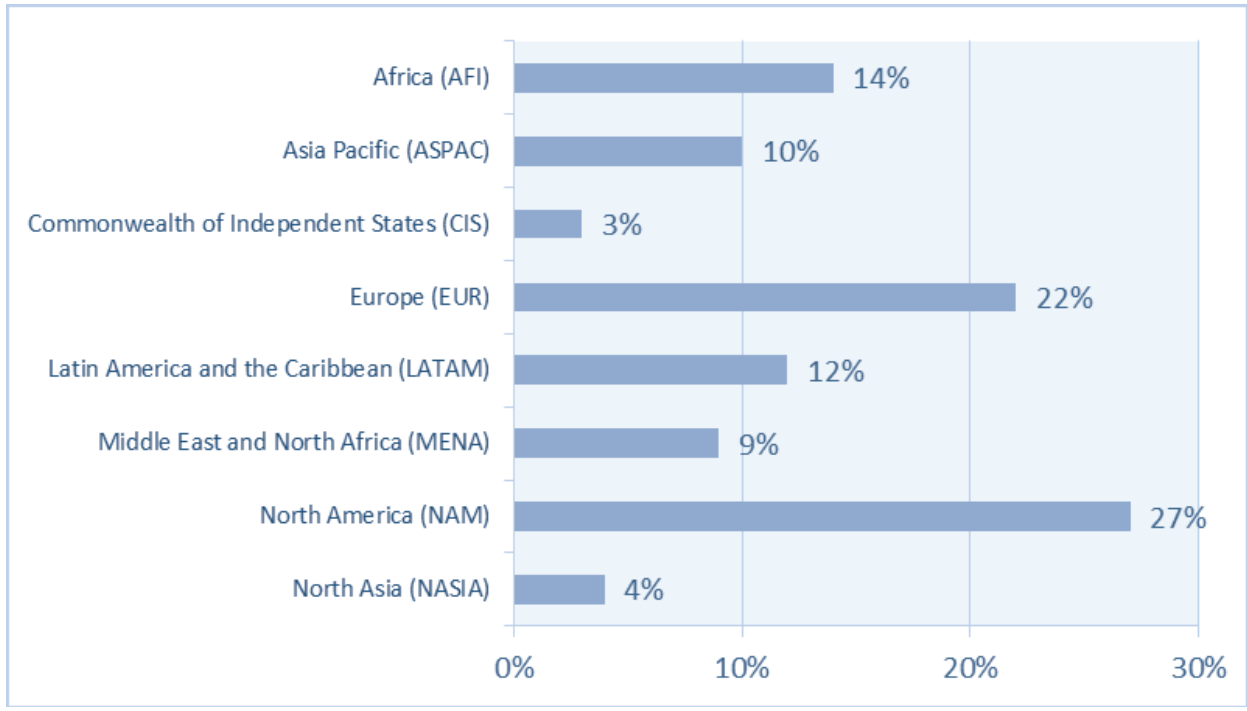

Źródło: IATA 2011

\section{NAUCZANIE FRAZEOLOGII LOTNICZEJ}

Nauczanie frazeologii lotniczej odbywa się w Polsce w ośrodkach kształcenia zawodowego, w tym w uczelniach wyższych przygotowujących do zawodu kontrolera ruchu lotniczego lub pilota. W większości miejsca te są też ośrodkami egzaminacyjnymi ULC. Instruktorami kursów frazeologii lotniczej są doświadczeni piloci i kontrolerzy ruchu lotniczego. W Polsce nauczanie frazeologii jest

${ }^{14}$ „W którym regionie najczęsciej zauważa Pan/Pani BRAK stosowania frazeologii lotniczej?” (tłum. A.B.). 
zatem zarezerwowane dla personelu operacyjnego. Często odbywa się ono podczas wykonywania zadań praktycznych. Frazeologia lotnicza traktowana jest wówczas jako narzędzie kształcenia zawodowego, a nie (sub)język specjalistyczny. Nie kształci się też regularnie nauczycieli angielskiej frazeologii lotniczej. Podczas dyskusji nad programami jej nauczania wyraźnie zarysowuje się aspekt praktyczny, mający na celu szybkie i sprawne jej opanowanie. Teoria ogranicza się do zagadnień związanych ze stosowaniem tejże frazeologii oraz technik jej bezbłędnego użycia. Skuteczne jej nauczanie wymaga od dydaktyków płynnego poruszania się w kontekście operacyjnym, nie jest możliwe zatem nauczanie frazeologii przez nauczyciela języka angielskiego, który nie ma doświadczenia bądź przeszkolenia w tym zakresie. Instruktor frazeologii lotniczej powinien mieć: ,special knowledge and ability to use the knowledge in teaching aviation specialists to contribute to flight safety by minimizing language radiotelephony communication failures" (Petrashchuk 2016, s. 77). Funkcjonowanie w grupie specjalistów wymaga posiadania, oprócz kompetencji czysto językowej, również kompetencji interkulturowej, pragmatycznej, dyskursywnej, a ponadto kompetencji zawodowej, czyli dysponowania pewnym zakresem wiedzy i umiejętności fachowych w danej dziedzinie, bez których wiedza językowa często bywa niewystarczająca, aby móc sprawnie i efektywnie uczestniczyć w procesie komunikacji profesjonalnej (Mamet 2002, s. 14).

Celem porównania możemy wyróżnić główne cechy nauczyciela ogólnego języka angielskiego oraz instruktora frazeologii lotniczej niebędącego nauczycielem ogólnego języka angielskiego. Zestawienie takie przedstawiono w tabeli 2. poniżej, wskazując na potrzeby w zakresie szkolenia nauczycieli języka angielskiego w rozpatrywanym kontekście:

Tabela 2. Porównanie kompetencji nauczyciela języka angielskiego i instruktora frazeologii lotniczej

\begin{tabular}{|l|l|}
\hline \multicolumn{1}{|c|}{ Nauczyciel języka angielskiego } & \multicolumn{1}{c|}{ Instruktor frazeologii lotniczej } \\
\hline wiedza lingwistyczna w zakresie ogólnego & praktyczne stosowanie frazeologii lotniczej \\
języka angielskiego i języka specjalistycznego; & i uproszczonego lotniczego języka angielskiego; \\
poziom języka angielskiego C1/C2; & znajomość procedur łączności lotniczej \\
umiejętność nauczania języka angielskiego & poparte wieloletnim doświadczeniem \\
z zastosowaniem zróżnicowanych metod na- & operacyjnym; \\
uczania; & wykształcenie kierunkowe - status specjalisty; \\
świadomość interkulturowej komunikacji; & doświadczenie zawodowe w lotnictwie; \\
umiejętność przygotowywania programów & wiedza praktyczna dotycząca wymowy języka \\
nauczania i ich dostosowanie do istniejących & angielskiego obowiązującej we frazeologii \\
warunków nauczania; & oraz pojawiających się w niej struktur grama- \\
przygotowywanie materiałów szkoleniowych. & tycznych; \\
& przygotowywanie materiałów szkoleniowych. \\
\hline
\end{tabular}


Wnioski wydają się oczywiste. Nie jest możliwe nauczanie frazeologii lotniczej bez doświadczenia, a przynajmniej bez odpowiedniego przeszkolenia nauczyciela języka angielskiego. W Polsce brak jest takich szkoleń. Nauczyciele języka angielskiego chcący udoskonalić swój warsztat w tym zakresie zdani są na kursy zagraniczne lub na samych siebie, co nie gwarantuje sukcesu w tak hermetycznym środowisku, jakim jest lotnictwo. Bezpieczeństwo każdego lotu musi być zapewnione. Nie ma tu miejsca dla braku kompetencji instruktora. Utrwalony błąd językowy może być trudny do wyeliminowania i może powrócić w najmniej oczekiwanym momencie. $Z$ drugiej strony, instruktor frazeologii lotniczej posiada wiedzę praktyczną, ale nie jest nauczycielem języka obcego. Jego metody nauczania mogą być nieprofesjonalne, a więc mało efektywne. Co więcej, nie możemy wykluczyć jego błędnej lub mylącej wymowy w języku angielskim, co zdecydowanie może doprowadzić do utrwalenia się błędu językowego u słuchaczy.

Podmiotem glottodydaktyki specjalistycznej w rozpatrywanym kontekście jest słuchacz, którego pierwszym językiem jest język polski (zob. Borowska 2011, s. 10). Podczas procesu przyswajania angielskiej frazeologii lotniczej wymaga się zwrócenia szczególnej uwagi na umiejętności słuchania i mówienia. Formy pisemne to w zasadzie tylko notatki sporządzane na podstawie usłyszanych informacji podczas éwiczeń do słuchania. Równolegle do kursu frazeologii lotniczej słuchacze uczęszczają na kurs uproszczonego języka angielskiego stosowanego w lotnictwie i tu szkoleni są już przez wykwalifikowaną kadrę dydaktyków języka angielskiego:

The specificity of AE teaching, which makes it different from any other ESP, is that language target skills are limited to two - Listening Comprehension and Speaking (Interaction) Skills with a special focus on pronunciation. The AE teaching is based on Communicative approach (CLT), learner centered approach, content-based syllabus and job place simulation. It is important that both teaching and learning objectives are documented by ICAO Cir 323 (Petrashchuk 2016, s. 77).

Clark i in. (w Hedge 2000, s. 45) zwracają uwagę, że nauczanie frazeologii lotniczej powinno stworzyć kontekst komunikacji docelowej, co ułatwi słuchaczom stosowanie frazeologii $\mathrm{w}$ warunkach operacyjnych. Materiały dydaktyczne zaznajamiają uczących się z wybraną terminologią, a także stwarzają im możliwości jej utrwalania dzięki odpowiednio dobranym ćwiczeniom. Co więcej, słuchacze powinni być zapoznawani ze specyficznego rodzaju „sposobem myślenia", charakterystycznym w środowisku operacyjnym. Programy nauczania zawierają te same zagadnienia w przypadku każdego kursu. Komponenty tematyczne szkolenia są ściśle określone. Mogą różnić się liczbą jednostek lekcyjnych lub sposobami interakcji, ale muszą zawierać te same niezbędne zagadnienia tematyczne, m.in.:

- informacje o poziomie lotu statku powietrznego,

- zgłaszanie pozycji statku powietrznego, 
- przekazywanie kontroli nad statkiem powietrznym i/lub zmianie częstotliwości,

- $\quad$ separacja międzykanałowa $8,33 \mathrm{kHz}$,

- zmiany znaku wywoławczego statku powietrznego,

- informacje dotyczące ruchu lotniczego,

- informowanie o warunkach meteorologicznych,

- meldunki dodatkowe,

- informacje lotniskowe,

- stan operacyjny pomocy wzrokowych i niewzrokowych lotniska,

- zredukowane minimalne separacje pionowe,

- plany lotów,

- czynności na płaszczyźnie lotniska i w przestrzeni powietrznej,

- służby dozorowania ATS,

- kontrola zbliżania,

- kontrola obszaru,

- $\quad$ sytuacje niebezpieczne i naglące (ICAO Doc 9432; Fellner \& Kozuba 2009).

Ponadto słuchacz powinien być świadomy zróżnicowania dialektologicznego języka angielskiego, a także różnic fonetycznych pomiędzy językiem angielskim a językiem polskim, takich jak np. długość samogłosek, wymawianie spółgłosek, akcent. Wydaje się oczywiste, że takie elementy kursu powinny być przedstawiane przez filologów języka angielskiego, którzy potrafią wskazać różnice w akcentach użytkowników angielskiego języka lotniczego. W przypadku frazeologii lotniczej wymowa została uproszczona poprzez wyeliminowanie dźwięków sprawiających trudności w wymowie osobom niebędącym rodzimymi użytkownika-

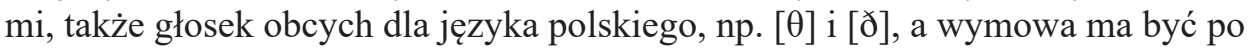
prostu zrozumiała bez konieczności wiernego naśladowania native speakers.

Zaleca się żeby każda jednostka dydaktyczna przeznaczona do nauczania frazeologii lotniczej opierała się na wykorzystaniu komunikatów i dialogów lotniczych z życia codziennego, które rozwijają sprawność słuchania i mówienia w kontekście ściśle zawodowym, a to przecież jest celem nadrzędnym. Poniżej przedstawiono przykład typowego ćwiczenia wprowadzającego nowe komunikaty (push-back routine - wypychanie), na podstawie jednego z najbardziej popularnych podręczników do angielskiej frazeologii lotniczej, w którym wyraźnie zaznacza się położenie nacisku na słuchanie ze zrozumieniem, utrwalenie wyrażeń przez powtarzanie, a następnie tworzenie własnych wypowiedzi:

Listen Listen to the recorded dialogues.

Listen and Repeat Listen to the dialogue again and repeat the pilot's words.

Write Complete the texts of these dialogues by writing in the pilot's words.

(a) Pilot: call control

ATC: control replies: SF153, roger, push-back approved.

Pilot:

$[\ldots]$

Listen and Speak Ask for push-back for flights 1-6 below. ${ }^{15}[\ldots]$

${ }^{15}$ F. Robertson, (1988). Airspeak, Radiotelephony Communication for Pilots. London: Prentice Hall International, s. 24-25. 
Nauczanie frazeologii lotniczej różni się zatem od nauczania (sub)języków specjalistycznych nie tylko ze względu na niezbędne w tej dziedzinie doświadczenie instruktora, ale przede wszystkim cel, jakim jest bezpieczeństwo lotu, precyzja i szybkość w nadawaniu komunikatów. Stosowanie frazeologii lotniczej pozwala na komunikację w przejrzysty, efektywny, jasny sposób, a odpowiednio stosowana nie jest dwuznaczna. W komunikacji lotniczej, w sytuacjach standardowych, nie ma czasu na parafrazowanie i wyjaśnianie nadawanych komunikatów. Nie ma też dostępu do wspomagającej zrozumienie mimiki czy gestów rozmówcy. Dlatego nacisk musi być położony na: komunikację głosową bez elementów mowy ciała, płynność, zrozumiałość, szybkość reakcji, tematykę związaną z pracą zawodową, symulację dialogów operacyjnych, precyzyjność i przejrzystość wypowiedzi. Szeroko rozumiana kompetencja komunikacyjna, obejmująca kompetencję lingwistyczną, socjolingwistyczną, strategiczną, czy kulturową, mająca na celu osiągnięcie skuteczności komunikacji i zdobycie umiejętności rozwiązywania problemów w komunikacji, nabywana jest przez słuchaczy na kursach uproszczonego lotniczego języka angielskiego.

\section{PODSUMOWANIE}

Podsumowując powyższe uwagi, trzeba stwierdzić, że angielska frazeologia lotnicza, jako swoista odmiana specjalistyczna, nie była dotychczas przedmiotem systematycznej i głębokiej analizy naukowej. Teoria nauczania frazeologii lotniczej nie zainteresowała do tej pory lingwistów w Polsce, a poza jej granicami tylko w niewielkim stopniu. Podkreślić trzeba także, że nie podjęto też prób ukonstytuowania stosownych badań w tym zakresie na płaszczyźnie akademickiej. Jedyny wyjątek stanowi tu Aviation Communication Research Centre ${ }^{16}$ (działający w ramach Instytutu Komunikacji Specjalistycznej i Interkulturowej Wydziału Lingwistyki Stosowanej Uniwersytetu Warszawskiego), w którym podjęto już takie badania.

\section{BIBLIOGRAFIA}

Borowska A., 2011, O konieczności usprawnienia procesu akwizycji lotniczego języka angielskiego na tle antropocentrycznej teorii języka, w: C. Dyrcz (red.) Publikacje z zakresu bezpieczeństwa $w$ portach lotniczych i morskich. Zeszyty Naukowe Akademii Marynarki Wojennej w Gdyni, Gdynia, s. 7-12.

Borowska A., 2012, Usprawnienie komunikacji pilot-wieża: zadanie dla lingwistyki języków specjalistycznych, w: S. Grucza (red.) Lingwistyka Stosowana, Vol. 5/2012, Warszawa, s. 19-29.

${ }^{16}$ acrc.iksi.uw.edu.pl 
Borowska A., 2016, Do Expert Speakers Need to Practice a Language?, w: A. Borowska, A. Enright (red.) Changing Perspectives on Aviation English Training, Warszawa, s. 61-72.

FAA (Federal Aviation Administration), 2009, Aeronautical Information Publication, 20th edition, US Department of Transportation.

Fellner A., Zając, J., 2008, Frazeologia lotnicza, Chełm.

Fellner A., Kozuba, J., 2009, Frazeologia lotnicza dla personelu latajacego, Warszawa.

Glen A., Marud, W., 2005, Kontrola przestrzeni powietrznej, Warszawa.

Hedge T., 2000, Teaching and Learning in the Language Classroom, Oxford.

ICAO Doc. 9432, 2007, Podręcznik radiotelefonicznej frazeologii lotniczej.

ICAO Doc 9426, Rozporzadzenie ministra infrastruktury z dnia 11 marca $2004 \mathrm{r}$. w sprawie zasad działania stużb ruchu lotniczego.

ICAO Doc. 9835, 2010, Manual of the Implementation of ICAO Language Proficiency Requirements, Montreal.

International Air Transport Association IATA, 2011, Pilots/Air Traffic Controllers Phraseology Study.

Mamet P., 2002, Relacja pomiędzy kompetencja językowa a kompetencja merytoryczna na przykładzie języka biznesu, w: J. Lewandowski (red.), Języki specjalistyczne. Problemy technolingwistyki, Warszawa, t. 2, s. 141-151.

Müldner-Nieckowski, P., 2007, Frazeologia poszerzona. Studium leksykograficzne, Warszawa.

Petrashchuk, O., 2016, Defining Competency Qualification of Aviation English Instructor, w: A. Borowska, A. Enright (red.), Changing Perspectives on Aviation English Training, Warszawa, s. 73-78.

Praktyczny słownik terminów literackich, 2003, red. H. Sułek, Kraków.

Robertson F., 1988, Airspeak, Radiotelephony Communication for Pilots, London.

Rozporzadzenie Ministra Infrastruktury z dnia 3 września $w$ sprawie licencjonowania personelu lotniczego (Dz.U. Nr 165, poz. 1603, z późn. zm.).

Źródła internetowe

Krasnodębska, 2010, http://dlapilota.pl/wiadomosci/dlapilota/icao-level-4-prawdy-i-mity-o-egzaminach-z-jezyka-angielskiego-w-ulc [12.07.2015].

Stownik języka polskiego, 2016, pod red. W. Doroszewskiego [online], sjp.pwn.pl [15.04.2016].

www.merriam-webster.com/dictionary [20.04.2016].

www.thefreedictionary.com/ [20.04.2016].

Anna Borowska

\section{TEACHING AVIATION ENGLISH STANDARD PHRASEOLOGY}

Keywords: aeronautical communications, Aviation English, aviation standard phraseology, standard phraseology trainer, standard phraseology teaching

Summary. Communication in Aviation English is crucial for aviation safety. Therefore, using Aviation English in the airspace has been regulated with the aim at reducing the risk of potential threats. Aviation English consists of two components: standard phraseology and plain Aviation English. The paper addresses the issue of standard phraseology presenting not only its scope, but also the Polish ambiguous equivalent 'frazeologia'. In its second part, the article demonstrates standard phraseology teaching techniques in the hermetic professional environment. The author also presents the major differences between a standard phraseology instructor and a typical English language trainer. 